\title{
Property Claims in Post-Gaddafi Libya: Political Debates and Justice Seeking in the Aftermath of Law $4 / 1978$
}

\author{
Suliman Ibrahim ${ }^{1,2,3}$
}

Published online: 19 December 2016

(C) The Author(s) 2016. This article is published with open access at Springerlink.com

\begin{abstract}
This paper charts evolving government policies towards property ownership in Libya, considers justice seeking by claimants who have been affected by Libya's Law 4/1978 on Real Property, and the regimes of property ownership proposed by the state when attempting to intervene in these disputes both prior to and in the aftermath of the 2011 Revolution. It also considers what leeway current political realities allow to formulate policy to deal with the aftermath of Law 4, before making some recommendations.
\end{abstract}

Keywords Law 4/1978 · Housing · Real property · Libya

In 1978, Mr O had plans for the land he owned in the centre of Tobruk, in the far east of Libya. It was more than 2000 square meters in size, and he managed to get a loan from

Suliman Ibrahim (PhD), Director.

This article is based on a research project on Access to Justice and Institutional Development in Post Gaddafi Libya, undertaken by the Van Vollenhoven Institute (VVI), Leiden University, and the Centre for Research and Consulting, Benghazi University. On behalf of the latter I coordinated the project as a whole and chose to do individual research on Law 4. I am indebted to Dr Jessica Carlisle of Manchester University Law School, then VVI's principal investigator on the project, who agreed to conduct a number of interviews on this topic and to collaborate in other ways. She has kindly agreed to make the results of her research available for this article for which I would like to thank her sincerely.

Suliman Ibrahim

s.m.k.ibrahim@law.leidenuniv.nl

1 Centre for Law and Society Studies, Benghazi University, Benghazi, Libya

2 Private Law Department, Law Faculty, Benghazi University, Benghazi, Libya

3 Van Vollenhoven Institute for Law, Governance and Development, Leiden Law School, PO Box 9520, 2300 Leiden, RA, The Netherlands 
the National Commercial Bank. His plans were, however, thwarted when, in the same year, the Gaddafi regime passed Law 4/1978 (from here on Law 4), under which it limited property ownership to one residence or plot of land on which to construct a residence for each male head of a household. The state appropriated Mr O's land and assigned it to the Public Company for Markets to use it as a public supermarket. Even when the company was later dissolved, and the running of the supermarket was assigned to a private investor, $\mathrm{Mr} \mathrm{O}$ did not manage to get his land back.

Things changed, it seemed, when the regime in 2006 formed a committee, known as the 2006 Committee, to address the effects of Law 4. Mr O was no longer alive by this point, but his heirs applied to the committee. To add pressure, they brought their case also before the Human Rights Society that was part of the Gaddafi International Charity and Development Foundation. The committee decided in September 2008 to give Mr O's heirs their property back, and ordered the Authority of Public Properties and the Authority of the Socialist Real Property Registry to register the property in their name. Yet, the latter refused to implement the decision. In February 2009, the General People's Committee (Libya's equivalent to a cabinet) issued a decision that exempted from restitution to former owners any public supermarkets and the land on which they are constructed; only compensation would be attainable. Mr O's heirs were obviously not happy with this outcome, and tried to change it. In August 2010, they brought their case again to the 2006 Committee to receive the following reply: "The committee has already taken its decision to assign the property to the former owners, and the relevant bodies [to apply to] are those who have been allocated the task of implementing that decision. If they refuse, the door is open to bring the case to court." However, Mr O's heirs did not go to court.

It was clear that, despite establishing the committee, the regime was not ready yet to seriously address the consequences of Law 4 . That would have required admitting that it was wrong to introduce this law in the first place. The regime rejected a proposal to this effect, ${ }^{1}$ and directed its attention to addressing what it termed the misapplication of Law 4. This could include expropriating one's sole property, or, when the expropriated property was in excess to the set limit, not compensating the owner. It was the committee's mandate to correct this misapplication, but, as Mr O's story tells us, it did not have that much to offer in this regard. Even the compensation that it could award was too low, as the head of the committee admitted. ${ }^{2}$

The time had not come yet for Mr O's heirs to get their grievances remedied. Luckily for them, this time they didn't have to wait too long. Just half a year later, the February 2011 revolution put an end to the Gaddafi regime, and the opportunity came for former owners to not only get their property back, but also receive full compensation for their lost earnings over the past decades. This was the conviction that Mr O's heirs shared with thousands of others affected by Law $4 .^{3}$ They were the victims of Gaddafi, the tyrant, to use their word, and so the revolution should

\footnotetext{
${ }^{1}$ See below: Decree 108/2006.

2 See Worth (2012).

3 There are many like Mr O's heirs. The effects of the expropriation of property under Law 4 are widespread in Libya, with estimates that as many as $75 \%$ of Tripoli's population live in properties that were affected by Law 4 (See Williams 2012, 30).
} 
remedy their grievances. They lobbied the transitional governments for that, and succeeded in getting the legislature, the General National Congress (GNC), consider a draft law obligating the state to sponsor the restitution and compensation schemes. ${ }^{4}$

However, the draft kept pending before the GNC until the current political and security crisis started in 2014. Since then, the country has become divided between two governments, and efforts to meaningfully address the legacy of Law 4 have come to a standstill. Admittedly, the GNC introduced in late 2015 two laws: Law 16 that retrospectively abolished Law 4, and Law 20 that addressed the consequences thereof. ${ }^{5}$ Still, it is unclear how useful these laws really are. Regardless of whether the GNC had the legitimacy to enact laws of any kind, which was seriously questioned, it lacked the authority to enforce these laws in, at least, half of the country, including Tobruk where Mr O's land is situated. As Mary Fitzgerald and Tarek Megerisi put it:

The post-revolutionary moment when it was still possible to debate housing, land, and property rights has now given way in Libya to conflict and chaos. Simply put, there is no government with the capacity to either enact or enforce any laws in this regard. This means that a whole new layer of complex grievances and widespread displacement will be added to the already toxic issue of property rights when the situation stabilises enough to begin seriously thinking about legal remedies. ${ }^{6}$

But can Libya afford to wait until "the situation stabilises enough to begin seriously thinking about legal remedies"? Given how widespread Law 4 grievances are, it is just a matter of time before the related conflicts will come once again to the forefront. Moreover, many of these conflicts are loaded with political and ethnic undertones. Former owners often regard themselves as victims of Gaddafi's regime and their opponents - the present occupiers - as the social and ethnic groups, which supported Gaddafi. If these property conflicts are not addressed properly, former owners, in the absence of alternatives, will be left with no choice but resort to violence to get their properties back, with high risks of escalation. ${ }^{7}$

To prevent this, there is in the first place a need for a unified government capable of enacting and enforcing laws addressing Law 4 grievances. In this regard, the UNbrokered Political Agreement between the conflicting parties has paved the way for such a government. This agreement has made possible a review of acts initiated by the GNC, and HoR, including Law 16 and Law 20. Reviewing these laws should

\footnotetext{
4 See below: After the 2011 Revolution.

5 See below: The Political Divide.

${ }^{6}$ Fitzgerald and Megerisi $(2015,20)$.

7 The existing literature on property issues in Libya, though limited, is indicative of the linkage between real property issues and security and justice. In addition to the paper of Fitzgerald and Megerisi (2015), there was a research project in 2013 by the American consultancy Tetra Tech that focused on this linkage; its title is quite indicative of that: Supporting the Justice and Security Sector through Property Rights in Libya (Available at: http://www.land-links.org/wp-content/uploads/2016/09/USAID_Land_Tenure_ SJSSPR_Synthesis_Report.pdf, accessed 20 January 2016).
} 
take into account what former owners, occupants and the wider society see as a just solution. To this end, a deep understanding of Law 4 - enactment, application, effect, and review - is needed. In fact, some writers argue that such an understanding is essential for solving the political crisis itself. They state:

Without an understanding of the history of Libyan property rights, both before and after the revolution, it is impossible either to understand how Libyan politics came to deteriorate so quickly, or to design a realistic path out of the current crisis. Disputes over property helped spark the post-revolutionary fighting, and they continue to fuel conflict today. The resolution of property rights issues also has a deeper significance. Before peace and prosperity can have any chance of succeeding in Libya, the country's citizens will have to resolve longstanding historical grievances in a manner which all perceive to be just. The conversations that will be required to fix the chaos over land and housing are the same kinds of conversations that will be required to create a stable political and economic system. ${ }^{8}$

This paper aims to contribute to such an understanding.

\section{Contesting Property Expropriation in Libya: A Socio-Legal Approach}

This paper charts evolving government policies towards property ownership in Libya, considers justice seeking by claimants who have been affected by Libya's Law 4, and the regimes of property ownership proposed by the state when attempting to intervene in these disputes, both prior to the 2011 revolution and in its aftermath. It also considers what leeway current political realities allow to formulate policy to deal with the aftermath of Law 4, before making some recommendations.

In order to do so, this paper reviews the effects of Law 4 on legalized property ownership and its distribution, and describes the resulting property disputes from the passing of Law 4 by the former regime. Firstly, it assesses how the Libyan government (under Gaddafi and after the 2011 revolution) enacted and reformed Law 4 and subsequently responded to the resulting protests, complaints and claims of property claimants: through the passing of legislation and the setting up of legal institutions, and through less formal policies of greater or lesser tolerance and acceptance of property claimants' demands. Secondly, it considers how property claimants tactically responded to the implementation of Law 4 and related legislation, their attitudes towards the inhabitants of disputed properties, and their conceptions of just solutions.

These two aspects of Law 4 related property disputes - property claimants' attempts to dispute their losses, and the opportunities and obstacles they encountered as a result of the policies of the Gaddafi regime and of the subsequent revolutionary and post-revolutionary governments - have taken place in shifting

\footnotetext{
${ }^{8}$ Fitzgerald and Megerisi $(2015,2)$.
} 
political contexts: before, during and after the 2011 revolution. The analysis of the ways in which law, legal processes and alternative strategies have been deployed by property claimants since 1978 takes this political flux into account.

The subsequent part of the analysis shows how property claimants' definition of what could be a just solution to their grievances became dominant in immediately post-revolutionary debates on Law 4, before becoming increasingly untenable throughout 2014 and into 2015.

The paper concludes by evaluating the development of a legal framework within which the state addresses the needs of claimants and occupants in property disputes, and by suggesting some priorities for future political responses by the government. These recommendations are made acknowledging that any comprehensive tackling of property disputes will remain impossible while the government is split.

The field research for this paper was largely conducted in Tripoli throughout late 2012 until the end of 2013 as part of a research project on Access to Justice and Institutional Development in Post Gaddafi Libya. It included interviews with property claimants, the Minister of Justice, bureaucrats, representatives of INGOs and the head of the 2006 Committee. ${ }^{9}$ In addition, files held by this committee on individual claims as well as the relevant archive of the Ministry of Justice were consulted. $^{10}$

Some of the property claimants interviewed were members of an association that has been active in lobbying post-Gaddafi governments in support of property restitution or full financial compensation. One interviewee's family lost an estate of several houses and shops and was not involved in the association. The other claimants interviewed were involved in disputes over the expropriation of only one property and were neither involved in a political struggle to reform Law 4, although they welcomed change. In the interviews with claimants they were asked to describe what had happened in their property disputes from 1978 until 2013, what they thought would be a just solution for both parties and what effects Law 4 had had on their family and neighbourhood relationships. In total six claimants were interviewed and a meeting of twenty more claimants during which they spoke about various aspects of their own disputes was attended.

In the interviews with members of the government, bureaucracy and the judiciary they were asked for a description of relevant events from 1978 until 2013, and for each interviewee's evaluation of likely future resolutions. This information was supplemented by files held by the 2006 Committee, internal government documents related to the establishment and working of this committee, and an analysis of the relevant laws and statements made by the Gaddafi regime related to property ownership.

\footnotetext{
9 The executors of this project were the Van Vollenhoven Institute (VVI), Leiden University, and the Centre for Research and Consulting, Benghazi University. On behalf of the latter I coordinated the project as a whole and chose to do individual research on Law 4. Dr Jessica Carlisle of Manchester University Law School, then VVI's principal investigator on the project, conducted a number of interviews on this topic and has kindly agreed to make the results of her research available for this article.

${ }^{10}$ Thanks are due to Mr. Salah El-Marghani, the, former, Minister of Justice, whose help made it possible to access the Ministry's archive.
} 
Shifts in Libyan government and policy have marked the history of Law 4 related disputes, and the accounts that property claimants give is of responding to and trying to make the best of these changes. Vandewalle has suggested that Gaddafi's regime can be understood in terms of differing ideological periods, which is adopted for this analysis of property disputes. ${ }^{11}$ The first of these, from 1973 until 1986, was dominated by Gaddafi's revolutionary theory that incorporated socialism, redistribution and nationalization. During the second period, which Vandewalle argues lasted from early 1986 until 2000, legal constraints on private property ownership were slightly relaxed in line with a shift in policies towards enabling private sector activity. This was followed by what might be termed a period of liberalization from 2000 until 2011, largely overseen by Saif Al-Islam (one of Muammar Gaddafi's sons, and his presumptive heir), during which there was further economic reform and some attempt to resolve grievances related to political repression. ${ }^{12}$ The penultimate period, an extension of Vandewalle's schema, began with the overthrow of the regime in 2011, extending through a period of transitional government, and elections and term of the GNC until late 2013. The final period, from late 2013 until late 2015, saw increasing political and military conflict resulting in two rival governments and self-declared, allied national armies.

\section{The Politics of Property in Gaddafi's Green Book}

Property disputes such as Mr O's originate in the economic ideas contained in Gaddafi's Third Universal Theory. These were outlined in the second part of his Green Book, 'The Solution of the Economic Problem: Socialism,' which was first published in 1975. Gaddafi asserted that an individual cannot be free unless he 'controls' his own basic needs, namely: a house, an income, and a vehicle. ${ }^{13}$ Ownership of property and income beyond the fulfillment of these basic requirements was deemed extraneous. Law 4 was consequently one of a succession of socialist policies pursued by the regime during the period March 1977 until March 1988 transposing aspects of the Third Universal Theory into law, which included nationalizations, the abolition of several private professions, limits to the role of the market and regulation of private property ownership.

The government that instigated these policies in the 1970s was unique. In theory, the Green Book provided for the organizational framework within which direct democracy was to be exercised. At the most basic level of this framework laid Basic People's Congresses in which every citizen who attained the age of eighteen was a member. Amongst the powers granted to these congresses was that of law making; any congress member could propose a law and when discussed and adopted by his own congress, and subsequently by other congresses, it would be made into law. The task of implementing those laws and any other decisions and policies was

\footnotetext{
11 Vandewalle (2012).

12 See Gebril and El-Tobuli (2013).

13 Green Book Part Two: 14-15.
} 
assigned to the People's Committees. ${ }^{14}$ In this system, Gaddafi was supposed to have no authority apart from that enjoyed by any other congress member. However, in practice, Gaddafi continued to play a significant role in the process of law making, e.g., setting the agenda for Basic People's Congresses' annual meetings, and giving instructions for how these agendas were to be discussed. ${ }^{15}$

It was not only Gaddafi who enjoyed exceptional powers in this system. In the mid-1970s, Gaddafi additionally announced that the 'people's authority' would be separated from the 'revolutionary authority,' creating the opportunity to build an alternative power base with which to "create a truly populist force that would enable him to rally the masses in support of his vision." 16 The resulting body was the 'Revolutionary Committees Movement,' a paramilitary institution which would operate in co-ordination with the people's committees in schools, universities, unions, the police force and the army. These revolutionary committees had more power than the people's congresses and "were not in any way regulated by legal statutes." 17

\section{Law 4: Fundamental Change to Property Ownership}

The implementation of Law 4 consequently occurred in a political environment in which governance was contested. Although sub-committees appointed by the General People's Committees in each municipality were supposed to undertake the expropriation and distribution of property under Law 4, as will be explained shortly, property claimants make it clear that the revolutionary committees were also involved in a process which they often found intimidating.

Law 4 states that every citizen has the right to own a house or a plot of land on which he can construct a house and that this 'ownership is sacred' (mulkiyya almaskin muqadisat) (Art. 1). ${ }^{18}$ The law prescribes that anyone in possession of an amount of (real) property in excess of this should choose which house or plot of land they wish to retain (Art. 2); additional properties will be transferred to the ownership of the state. This includes all buildings, regardless of whether they are fit to be used as houses, except those used by the owners for purposes related to their job, craft, or industry, as well as any vacant plots of land prepared or fit for building on (Art. 3). Excess properties will then be assigned to citizens who are in need of housing, although the law also allows the state to keep these properties to serve the public interest (Art. 7). This was specifically what happened with Mr O's land. The law entitles those whose property is expropriated to compensation (Art. 8), however it refers to enforcement regulations (laiha tanfithia) to determine the method of payment.

\footnotetext{
14 Otman and Karlberg (2007, 64); Pargeter (2012, 87); St John (2011, 62).

15 Al-Mgaryaf, Mohammed Yousef, extracts from Libya from the Constitutional Legitimacy to Revolutionary Legitimacy, http://tinyurl.com/sjpgl-061, accessed on 16/01/2016. Pargeter 2011: 112.

16 Pargeter $(2012,97)$.

17 St John $(2011,64)$.

18 The legislation assumes that property ownership is a male prerogative.
} 
The accompanying legislation for enforcement mandated the setting up of two committees in each municipality. The first of these was tasked with identifying the properties subject to Law 4 and receiving the statements that all property owners were required to complete providing a detailed account of the number of real properties owned, the names of the tenants and the purpose of the tenancy, the number of wives and sons of the property owner, and any requests for immediate family members to be allocated ownership of surplus properties. The law mandated property owners to submit this information to the committee within two months of the issuing of the regulation. The second committee was given the responsibility of assigning the ownership of these properties to those in need, provided that its decisions on this matter were approved by a higher committee formed by the General People's Committee. To this end, it had to determine the value of the property in question. ${ }^{19}$

Although it seems that some property owners managed to avoid the consequences of this legislation, such stories are anecdotal. There was some scope to retain more than one property within a family within the terms of the legislation, given the rule that every male adult was entitled to a residence. As a result, some property owners registered relatives as the owners of property that was at risk of being expropriated. This response had mixed results: while some families successfully managed to hold on to property in this way, this strategy caused long-lasting rifts in other families, with relatives subsequently falling out over who had the strongest claim to rightful ownership. In the case of some property owners, their ownership remained undetected, but this situation does not seem to have been widespread in Tripoli and Benghazi and there are instances when neighbours informed on each other when property ownership had not been reported. Mr M, who was a child at the time, thinks that his family did not submit the required paperwork, but adds that this did not prevent them from being affected by the legislation.

Mr M consequently describes the impact of Law 4 on his family as immediate and costly. He says that his family owned a considerable amount of property across Tripoli in the early period of Gaddafi's regime, including shops and housing in the old city (al-madina al-qadima) and several tracts of land, amongst which was a 200 hectare plot which is still currently undeveloped since it is occupied by a government ministry. He describes two broad processes by which the property was lost: it was either kept by the sitting tenants, or taken by the regime. The shops and residential property in the madina were claimed by tenants as soon as Law 4 was passed; they simply stopped paying rent to the former owners. The family's land was expropriated incrementally by the regime. The land, now belonging to a government ministry, had already been appropriated by the Italians, who used it for farming and agricultural development. ${ }^{20}$ Following independence this land was due to be returned to the family, but this had never been implemented by the monarchy. As a result it fell to the Gaddafi regime and was kept by it. Mr M says that the smaller farm, which now contains a car park, was expropriated by the people's committees, who retained some of it for their own purposes and redistributed the

${ }^{19}$ Law 4 Enforcement Regulations. See al-Jarida al-Rasmia (Official Gazette) No 4, 31/5/1978.

${ }^{20}$ Italy colonised Libya from 2011 until after World War II. 
rest. He notes that his family could do nothing to oppose these expropriations, describing the people's committees as criminal gangs who drank and terrorized their neighbourhoods.

Most property claimants had a story in which a member of their family had been arrested, if not as the result of a property dispute then in relation to an act that the regime regarded as some kind of infringement of its rules and policies or as a suspicious activity. Mr M's belief that the involvement of the people's committees and the revolutionary committees in the implementation of Law 4 enabled significant amounts of corruption is reflected in most claimants' descriptions of being powerless to stop people they regarded as allies or affiliates of the regime from profiting from their losses. Property claimants tell stories about money changing hands in order for people to be allocated plots of land on which to construct a house by the people's committees (and then later the real property registry $)^{21}$ and of people with connections exploiting the law to accumulate property or move into a bigger house. ${ }^{22}$

In theory, property owners were to be compensated for their losses. Legislation regulating the implementation of Law 4 states that the estimation of the value of each property had to be based on the price of the land and any building or installation(s) constructed on it at the time that the property was expropriated. The basis of this evaluation was stipulated in a decision issued by the Law 4 High Committee. $^{23}$ The regulation further distinguished between two groups of recipients. The first included ex-owners who had a limited income and those who depended for their living on renting a property. To them, compensation had to be paid in full. All other recipients were only entitled to immediate full payment of compensation if the value of the property was less than LYD 10,000. If it exceeded this amount, it would be paid in annual installments of LYD 10,000. The payment in this case took the form of bonds that the Treasury would issue in the name of the exowner. $^{24}$

The significance of provisions for compensation under Law 4 was largely dismissed by the property owners interviewed. Most said that they had not received any compensation and that they would not have expected it from the regime, noting that in any case property was significantly undervalued. Still, establishing the right to compensation formed a basis that later Gaddafi's regime, the subsequent National Transitional Council (NTC) and the subsequent GNC have each reconsidered, as property disputes have dragged on for three and a half decades.

\footnotetext{
21 In 1979, a decree issued by the General People's Committee amended Law 4's Enforcement Regulations, annulling all Law 4 committees, and awarding the task of identifying properties subject to Law 4 and redistributing them to the offices and directorates of Real Property. See Muzughy No Date: 437-439.

22 A report from the Libyan regime's Public Administration Control Authority in 1986 noted that such infringements had taken place. See Muzughy No Date: 470-472.

23 Article 15, Law 4 Enforcement Regulations.

24 Article 21, Law 4 Enforcement Regulations.
} 


\section{The Revolutionary Decade: Increasing Property Restrictions until 1988}

Property claimants state that in the immediate period after the passing of Law 4 they were in a weak position to contest either the way in which their property had been expropriated, or the realities of the compensation provisions made by the government. In 1979, a decree issued by the regime's cabinet, the General People's Committee, amended Law 4's Enforcement Regulations. Under this amendment, all committees specific to Law 4 were annulled, and the task of identifying properties subject to Law 4 and of redistributing them was assigned to the offices and directorates of the Real Property Registry. In addition, every citizen occupying a house was to be considered its owner, provided that he met the conditions stipulated in Law 4 and its Enforcement Regulations, ${ }^{25}$ with the exception of two situations: when a house was illegitimately occupied, and when it was the only property of an owner who was abroad either studying on a Libyan government scholarship, or doing work he was legally permitted to do. ${ }^{26}$

The regime further reformed their property expropriation policies and extended the policy's reach by passing Law No 21/1984 'Concerning Special Regulations on Public Utility and the Disposal of Land. ${ }^{, 27}$ This legislation extended the application of Law 4 to any vacant plot inside and outside of the urban planning area, including former agricultural land which had been changed by constructing camps or rubbish collection centres. ${ }^{28}$ The law also amended the way in which dispossessed property owners should be compensated by making a distinction between plots of land and buildings. The amount of compensation awarded for land was to be determined by a decision issued by the General People's Committee, while compensation for buildings remained subject to Law 4 .

Another significant development concerning awards for compensation came in the following year. Law 7/1985 'Concerning Special Regulations of Compensation Lawsuits Related to the Application of the Revolutionary Statements' stated that courts were prevented from accepting any lawsuits requesting compensation for any misapplication of revolutionary statements, and suspended any similar lawsuits previously brought before them. Furthermore, this law prevented the enforcement of any court judgments issued in such cases if they had not already been enforced. ${ }^{29}$

\footnotetext{
25 According to Article 5 of Law 4's Enforcement Regulations, in order for anyone to be assigned the ownership of a house he was occupying, he would have to: 1) be a Libyan citizen, 2) be married; to be a breadwinner for children, parents or siblings who lived with them; or to be alone with no one supporting him, and 3) not already own a house or a plot of land on which he could construct a house.

26 Al-Jarida al-Rasmia (Official Gazette), Issue No 33, 12/12/1979.

27 Al-Jarida al-Rasmia (Official Gazette), Issue No 29, 8/11/1984.

28 Judge Yussef El-Hanesh, the Head of the 2006 Committee, summarised the effect of Law 21/1984 as follows: all land and buildings constructed thereof became state property except: what was owned by embassies, productive farms, the sole house, the sole plot of land on which to build a house, and the sole workshop. His reply to a report by the Financial Auditor, dated 23 January 2010.

29 This law was subsequently challenged on the grounds that by imposing such restrictions it prevented people from their right to litigation and so was unconstitutional; however, the Supreme Court concluded that this law did not prevent people from bringing cases; it only regulated this right. See Maghur (2008).
} 
The law added that these restrictions were to continue until new legislation was issued regulating the application of the revolutionary statements. This did not happen until the passing of Law No 5/1988, which established the People's Court. ${ }^{30}$

A further restriction on property ownership took place when the Green Book's statement 'land is no one's property' was made into law. In 1986, Law 7 abolished the ownership of land ${ }^{31}$; instead, it emphasized that "Everyone has the right to use or to benefit from [land] by working, farming or using it for pasture." 32 The impact of this on Law No 4/1978 was to reformulate the meaning of property ownership, continuing to restrict people to the ownership of one house, but redefining the right to land as one of usufruct (intifa'a) instead of ownership. This point was clearly stated in accompanying legislation, issued on the same day as Law No 7, viz. Law $6 / 1986 .{ }^{33}$ The implication of the introduction of this law for potential property claimants was that claiming compensation for the loss of a plot of land was rendered impossible.

\section{Apparent Expansion of the Scope for Property Claims until 2000}

The regime's stance on expropriated property seemed to change in March 1988, when it adopted a more relaxed attitude towards the implementation of Gaddafi's thoughts. In practice, however, this relaxation was partial since it did not reflect any substantial shift away from Gaddafi's ideology. Moreover, this relaxation did not last.

The regime's revised policies towards property were a reaction to both domestic and international pressures beginning in 1986 and to the condemnation by international human rights organizations and foreign governments of its human rights' record. A particularly significant change during this period was the issuing of Law 5/1988, which established the People's Court. Under this law, this court was given jurisdiction over a number of legal claims including those concerning "annulment, restitution and compensation for any misapplication of revolutionary statements." A number of 'misapplications' were detailed in a report published by the Public Administrative Control Authority in 1986. They included assigning ownership of a property to more than one person, or more than one property to one person, or to one who occupied it by force, or without satisfying the required conditions, or based on favouritism and personal connections. The official admission of these transgressions contained in this report ${ }^{34}$ and a speech by Gaddafi $^{35}$ opened the door to property claims in the People's Courts for the restitution of some property or compensation for its loss.

\footnotetext{
30 The people's courts were established under Law 5/1988 (Al-Jarida al-Rasmia (Official Gazette), Special Issue, 1/6/1988). They operated outside of the formal justice system and largely dealt with cases related to revolutionary legislation, such as Law 4 and perceived political crimes.

31 Article 1, Law 7/1986.

32 Article 2, Law 7/1986.

33 Al-Jarida al-Rasmia (Official Gazette), Issue No 14, 3/6/1986.

34 See Muzughy No Date: 470-472.

35 Ibid: 25-36.
} 
The research on the involvement of these courts is not sufficiently advanced to be able to make a meaningful assessment of their impact on property disputes. However, it should be noted that at their inception they were not staffed by qualified judges, but by individuals appointed by the General People's Congress from amongst a pool elected by the Basic People's Congresses. ${ }^{36}$ The interviewees only described using the courts successfully in the 1990s. However, the opportunity afforded by the People's Courts was to last for only four years.

In 1992, Law 11 'Concerning Special Regulations of Real Property Ownership' was passed restricting claimants' rights to address 'misapplications' related to the implementation of Law 4. This new legislation disallowed the restitution of any houses expropriated in accordance with Law 4, and suspended all legal claims demanding that such action be taken. Furthermore, any judgments ordering restitution that had already been issued, but had not yet been executed, were deemed non-enforceable. The only enforceable ruling under this change was compensation that the law described as 'fair'.

A sole exception was made for workshops that had been used by a former property owner for the purpose of his job, industry, or productive or commercial craft. Such premises could be subject to restitution by the People's Court provided that the claimant proved that that workshop was his own, that he was using it when it was expropriated, and that it was not otherwise used in the interest of society. The claimant also had to promise to man the workshop through his own work and that of his family without 'exploiting others'. In addition, he was required to file his lawsuit within one calendar year starting from the date that Law No 11/92 entered into effect and the claimant could only recover one workshop. ${ }^{37}$

Despite the new restrictions brought about by Law 11/1992, it could be argued that people with a grievance arising from Law 4 were nevertheless able to file their complaints and to have some of them, at least partially, settled. However, this small window of opportunity only lasted five years. Then, the regime enacted a u-turn regarding property claims. Law 7/1997 'Concerning the Amendment of Some Provisions of Law No 5/1988 on the Establishment of the People's Court' was passed limiting any lawsuits concerning compensation for any misapplication of revolutionary statements to those related to 'personal' (rather than 'real') property (al-amwal al-manqulat). ${ }^{38}$ Moreover, Law No 10/1997 on 'Special Regulations of Ownership, Expulsion, and Eviction Lawsuits Concerning Real Properties Allocated to Society' forbade legal claims for the restitution of the ownership of real property, even if the property was vacant. ${ }^{39}$ These two new pieces of legislation effectively meant that compensation for any real property (a house or workshop) became, once again, unobtainable.

\footnotetext{
36 Article 2, Law 5/1988, Al-Jarida al-Rasmia (Official Gazette) (Special Issue), 1/6/1988.

37 Al-Jarida al-Rasmia (Official Gazette), Issue No 27, 1/10/1992.

38 Al-Jarida al-Rasmia (Official Gazette), Issue No 10, 29/5/1997.

39 Al-Jarida al-Rasmia (Official Gazette), Issue No 2, 21/2/1998.
} 


\section{Decree 108/2006: Introducing State Sponsored Compensation}

The constant flux in legislation on expropriated property throughout the 1990s, while the regime was pursuing ambivalent policies towards the private sector, coincided with a period of economic depression, resulting from Libya's confrontation with the West and domestic political mismanagement. Reform was, consequently, forced upon the regime. Throughout 2000 until the 2011 uprising, the regime introduced significant legal and political changes permitting ownership of more than one property in several situations, allowing for restitution of, or compensation for, expropriated properties, and raising the possibility of ending Law 4. During this decade the regime, under partial direction of Saif Al-Islam Gaddafi, encouraged foreign investment and forged strong links with the international community. Some of the effects in Tripoli were a steady and steep rise in property prices, and the amassing of considerable wealth by a few, particularly those affiliated to the regime.

The first indication that the regime was altering its stance came with Law 3/2004. This legislation lengthened the list of family members who could claim rightful ownership of family property, such as widowed daughters. It also allowed people to own more than one property if they had needed to step into support a family following the death of the original head of household. In addition, ownership of multiple properties was permitted if the purpose was to speculate on it or to temporarily rent it out as housing. ${ }^{40}$

The second, more important, change was brought in via Decree 108/2006 'On the Procedures, Bases and Criteria Concerning the Completion of the Compensation for Properties Subject to Law No 4/78.' This decree enabled both some restitution of properties and the awarding of compensation for their loss. The decree permitted restitution to pre-1978 owners and their adult sons, of houses and plots of land (one per person) ready for the construction of houses if the property had been used or invested in by the state (public law persons and public companies), and had never been conclusively registered in the Socialist Real Property Registry in the name of a Libyan citizen. ${ }^{41}$ There was a similar provision for the restitution of workshops, which could be returned to the original owner and his adult sons (one to each person) if it had never been conclusively registered in the name of a Libyan citizen. If restitution was unattainable, the decree allowed for compensation of the original owners.

The property claimants interviewed were all aware of the 2006 Committee and all had opinions about it. In $2006 \mathrm{Mr} \mathrm{H}$ photocopied all of the documents related to his property losses and took them to the committee. When asked how he came to decide to go ahead with this, he reasoned that he was persuaded by what people were saying while talking about it amongst themselves. $\mathrm{Mr} \mathrm{M}$ also submitted documents for which he got a receipt. However, he was dismissive of the regime's

\footnotetext{
40 Mudawwanat Al-Tashriyy'at (Official Gazette) No. 3, 31/3/2004.

41 Law 4 while stipulating that properties expropriated were to be redistributed to those in need, permitted the state to keep some properties and 'manage' them in the interest of the Libyan people, whether these properties were houses or otherwise, provided that they had been owned by, or rented to, non-citizens (Article 7/b).
} 
motives for establishing it: "Once in a while the government set up a committee to satisfy people, but it was usually a joke."

By the outbreak of the 2011 revolution, the Committee had gathered 25,000 claims, 8,000 of which it states that it had settled. ${ }^{42}$ None of the property owners interviewed had received any compensation or restitution of property from the Committee. Those that did either got lucky, or paid a bribe in order to get a result if they were desperate enough and "were in a bad situation." During a meeting to establish an association for female property claimants in Tripoli in February 2013 there was consensus that the compensation offered did not reflect property prices, and one woman angrily complained that, like $\mathrm{Mr} \mathrm{O}$, the Committee had supported her right to repossess one property, but she had not been able to enforce this order through the courts. ${ }^{43}$

The legacy of Law 4 was one subject of a body set up during the 2000s, as part of the reform efforts supported by Saif Al-Islam. The Civil Code Review Committee was created to review the Libyan civil code and related laws and to consider whether to replace or amend them. The Committee recommended that 'exceptional' laws, which had been brought into address social ills such as unequal wealth distribution, should be abolished including Law 4, Law 21/1984, Law 7/1986 and Law 10/1997. However, this recommendation would not be applied retrospectively; as a result, those who had already gained property as a result of the application of these laws would not be affected. ${ }^{44}$ In the end, this recommendation was not followed through by the regime. Property claimants subsequently had to wait until the 2011 revolution before the opportunity came to press the government for substantial review of Law 4.

\section{After the 2011 Revolution: The Overthrow of the (Property) Regime?}

The $17^{\text {th }}$ February revolution ending Gaddafi's regime radically altered the political landscape and enabled challenges to legislation based on Gaddafi's Third Universal Theory, such as Law 4. By 2013, the emergence of a democratic government and the space which now opened up for protest and lobbying made Law 4 seem politically unsustainable as property claimants demanded justice. While some claimants resorted to violence to repossess their lost property, others organized collectively in order to demand legal reform.

The government's lack of the monopoly of violence given the continued presence of militia on the streets, and the weaknesses of the army and police, gave some families the opportunity to seize lost properties back by force. There are stories of militia forcibly evicting occupants since the revolution. A widow in her early $60 \mathrm{~s}$, Mrs S said that a friend of her son arranged at the end of 2012 for a militia in Tripoli

\footnotetext{
42 Statistics received from the Committee in December 2012.

43 The judge presiding over the 2006 Committee admitted that the compensation offered was too low. See Worth (2012).

44 The committee's proposal can be found, in Arabic, at: http://www.startimes.com/?t=32038375, accessed on 20/01/2016.
} 
to reclaim two of the nine villas that her father owned in 1978, all of which were expropriated. Interviewees noted, however, that some people could not be evicted since there is considerable fear that the occupants are armed, or have connections with groups that have weapons. Moreover, there are accounts of militia (many of them said to be opportunists who banded together after the revolution) taking properties for themselves, particularly after they have been abandoned by occupants allied to the old regime. For claimants who do not have access to weapons or force there is a risk that they will find themselves subject to criminal prosecution.

In the atmosphere of uncertainty about future government policy towards Law 4, dozens of claimants with enquiries about their disputes still in late 2013 visited the 2006 Committee every weekday. The Committee's staff said that they also received enquiries from occupants wanting to know if claimants on their residences had previously accepted compensation, and that they occasionally received a request from a claimant together with an occupant to formalize an agreement they had reached between themselves. Anecdotal stories about voluntarily settlements, both before and after the 2011 revolution, were also sometimes related by property claimants interviewed, although none of the people interviewed had reached such agreements themselves.

Apart from attempts at self-help and mediation, some property claimants formed civil society organizations in order to lobby for their rights to expropriated property in the immediate aftermath of the revolution. The most high-profile of these CSOs is the Rabitat el-Mulak el-Mutadarariyn min Hukm el-Taghyat (Association of the Owners Harmed by the Ruling of the Tyrant), which stated in 2013 that it had 1,300 members, maintained a Facebook page and frequently appeared in the media. These groups were well connected in 2012-13: the Rabitat maintained regular contact with the head of the 2006 Committee and within the GNC and was active in lobbying the Ministry of Justice. ${ }^{45}$

In response to the increasing pressure to deal with the property issue, the head of the 2006 Committee made a draft law to annul Law 4. To the same end, the Rabitat itself also submitted a draft law to the Council of Ministers. The Prime Minister then issued Decision 13/2012 to form a committee headed by the Minister of Justice to review these drafts. The way the review committee worked clearly shows the Rabitat's significant level of influence. The committee held two meetings (12/03/ 2012 and 17/03/2012), which ended in making a new draft and submitting it to the Council of Ministers. However, the Council, twice, returned the draft to the committee to consider comments made by the Rabitat. The third and fourth meetings (02/05/2012 and 06/06/2012) were attended by representatives of the Rabitat and some of their demands were taken into account. ${ }^{46}$

The drafts of both committees provide an interesting insight into the recognition of property claimants' demands in 2012-13. Unlike what was initially proposed by the 2006 Committee, the draft submitted to the GNC did not propose to end Law 4.

\footnotetext{
${ }^{45}$ In an interview on 19 December 2012, Judge Yussef Hanesh, head of the 2006 Committee, said that "Rabitat al-Mulak is in collaboration with us [the Committee].".

46 The minutes of the committees' meetings and the letters exchanged are part of the archive of the Ministry of Justice to which Mr. Salah el-Marghani, the, former, Minister of Justice generously gave us access to.
} 
As clarified in the explanatory memorandum accompanying the proposed law, the application of Law 4 over a period of more than three decades led to established rights for many bona fide citizens, and it would be legally unacceptable to end these rights through a retrospective abolishment of the law. What was needed was to address the effects of Law 4 on a case-by-case basis, and make a distinction between cases where restitution would be possible and others where only compensation would be awarded.

Apart from this, the 2012 Committee draft did not significantly differ from that of the 2006 Committee. Concerning the claimants, both drafts started from a position where restitution is the rule, and compensation is the exception. The wording, however, was different. The 2006 Committee draft proposed the restitution of any real property without making a distinction between workshops, land and houses. The 2012 Committee draft made such a distinction. It first proposed that workshops, vacant plots inside urban planning areas and agricultural land on which installations had not been built, be subject to restitution regardless of the occupants' status. It then proposed that housing be returned, except in five cases, namely if the claimant had already been compensated, if he preferred compensation over restitution, if there was reconciliation between himself and the occupant, if the ownership had been seized for public interest and the execution of the public project had begun before the effective date hereof, or if the value of the property was not appropriate in respect of the value of the installations built thereon. The difference between the drafts was, still, insignificant as the 2006 Committee draft included similar exceptions. Also, both drafts entitled claimants to demand compensation to make up for the difference between that paid out by the 2006 Committee and that which was fair, taking into account lost earnings.

Regarding occupants, the drafts were also roughly similar. The 2006 Committee draft proposed that if the occupant did not have another property, then he should be allocated a state-owned property with the obligation to pay a mortgage on it. Alternatively, an occupant could be given adequate compensation. The 2012 Committee draft had the same provision (Article 10). It also went on to state that if restitution was ordered, but the property was occupied by a Libyan family and it was not immediately possible to provide them with a state-owned house, the state should allow them to stay in the house for a period of time to be determined by the Council of Ministers. The relevant ministry would pay the owner the estimated market rent. However, the family would be obliged to find alternative accommodation within this time; otherwise, they would be evicted once it ended (Article 6). It seems on first reading that Articles 6 and 10 may not have been reconcilable: however, one interpretation of their interaction might be that the stipulation in Article 10 would follow on from Article 6, meaning that a family would remain in a property during the period determined by the Council of Ministers before moving into governmentprovided housing or receiving compensation. As such, this draft was no different from that of the 2006 Committee.

The noteworthy difference between the two drafts is, perhaps, the provision added in the 2012 Committee draft that the proposed law would not violate any measures taken concerning the restitution of and compensation for properties per Decree No. 108 of 2006 (Article 11). Given that according to this decree restitution 
was limited to one house, there could be cases where claimants were denied the restitution of their multiple properties, and awarded, instead, compensation. In these cases, they could not apply for restitution under the new law. Still, under the proposed law, they could ask for the difference between the stipulated amount of compensation and what would be deemed fair. Also, the application of this provision was rather limited because not all claimants resorted to the 2006 Committee, this committee managed to decide only on a third of the cases it was presented with, and not all decisions were enforced.

It is fair, then, to say that the drafts made by the 2006 Committee and the 2012 Committee were quite similar. Given this similarity, the abolishment of Law 4 by the 2012 Committee should rather be regarded as symbolic. Yet, the Rabitat sent a letter to the Minister of Justice on 24 April 2013 criticizing the 2012 Committee draft bitterly. The criticism focused mainly on the omission of the abolishment of Law 4, and employed a language and argument that were, as the Justice Minister put it, of a political rather than a legal nature. The Minister pointed out that the Rabitat contributed to the writing of the draft; if it denied that, the Rabitat should explicitly declare that, after which he would withdraw the draft from the GNC. ${ }^{47}$

The Rabitat, however, did not make such a declaration. Instead, it successfully lobbied the GNC for a new draft law on 'the Restitution of Real Properties'. It kept close contact with the GNC's committees responsible for making the draft, and once it was ready pressured the GNC into adopting it. For instance, on 3 October 2013, the Rabitat organised a sit-down protest in front of the GNC's premises demanding that the GNC quickly look into the draft, holding it responsible for any delay that could disturb security and stability and increase frustration amongst citizens, and asking for the discussion of the draft to be broadcast live. ${ }^{48}$ The Rabitat also submitted a proposal for 'minor amendments' to the draft. ${ }^{49}$

The new draft incorporated most of the Rabitat's demands. It would retrospectively end Law 4, order the restitution of lost property, the payment of an amount equivalent to the rent that the owner would have collected since the expropriation, and another payment to refurbish the property. If restitution would be unattainable, a fair compensation would need to be paid. The occupant would stay in the residence for a maximum of one year as a tenant. Meanwhile, the state would provide an alternative residence if the occupant was unable to get one on his own.

To the disappointment of the Rabitat, when the GNC discussed the draft on 29 December 2013 it did not adopt it. According to the spokesperson of the GNC, there were three considerations: remedying the grievances of former owners, protecting rights of bona fide occupants, and preserving societal peace, and any draft law should take them all into account. The GNC decided, he stated, to take its time in

\footnotetext{
47 The letter, on which the Minister's notes were written, is published on the Ministry's webpage: http://itcadel.gov.ly/2013/04/المعروضة_المذكرة-على_العدل-وزير -تعليق/201/.

48 A letter of the executive manager of the Rabitat dated 17 December 2013. Published on the Rabitat's Facebook page: https://www.facebook.com/PropertyOwnersLibya/, accessed 20 January 2016.

49 A letter of the executive manager of the Ratbitat to the head of the GNC dated 1 December 2013. Published on the Rabitat's Facebook page: https://www.facebook.com/PropertyOwnersLibya/, accessed 20 January 2016.
} 
thoroughly studying the draft. ${ }^{50}$ The GNC, it turned out, did not have that much time.

\section{The Political Divide: What Now for Property Claimants?}

In late 2013, a growing sense of frustration with the GNC's performance developed into popular calls for an early step down. The GNC had to give into these calls, and amended the Constitutional Declaration on 11 March 2014 so a newly elected House of Representatives (HoR) could replace it. The HoR was elected on 23 June 2014, but the succession was far from smooth. On procedural grounds, the GNC refused to hand over to the HoR that convened in Tobruk in the far east of Libya. Meanwhile, the GNC continued to act as the legitimate legislature. At first, there was little doubt about the legitimacy of the HoR, and it was internationally recognized as Libya's sole legislature, but the Supreme Court issued a ruling on 6 November 2014 deeming it unconstitutionally formed. The HoR rejected the ruling, arguing that it was made under duress; still, its claim to legitimacy was nonetheless debilitated. Now, the country is practically divided between the two bodies, each with its own cabinet and armed forces. ${ }^{51}$

The division between the GNC and HoR was framed in various ways, including, from the GNC's perspective, revolutionaries v. Gaddafi loyalists, and from the HoR's view, nationalists v. Islamists. Both statements have some merit. Unlike the HoR, the GNC has been widely dominated by revolutionaries, most of whom happened to be Islamists. As such, the GNC adopted a view, which could be termed revolutionary, that held that achieving justice requires a complete severance with the legacy of the Gaddafi regime, including any laws the regime introduced, institutions it established, and people it relied on. This view can be identified in several of the GNC's laws such as the Transitional Justice Law 29/2013 and Law 13/2013 on Political and Administrative Isolation. Both privileged those associated with the February revolution while harshly dealt with their opponents, i.e., truly or allegedly perceived to be Gaddafi loyalists. ${ }^{52}$ No room was given to those loyalists to voice their demands or concerns.

Similarly, in addressing the effects of Law 4, strong claimants ably participated in the process of writing draft laws meeting their demands in a complete absence of occupants. Clearly, the association of those occupants with the old regime played a significant role in marginalizing them in the debates on Law 4. In fact, those strong claimants managed to make the GNC issue one of these drafts at a time when many thought that addressing the Law 4 legacy was no longer a priority. On 1 June 2015,

\footnotetext{
50 The statement is posted on the Facebook page of the GNC' spokesperson: https:/www.facebook.com/525137757503749-المتحدث_الرسمي-باسم-المؤتمر -الوطني-العام-عمر -حميدان//, accessed 20 January 2016.

51 For a more detail description of the situation, see: International Crisis Group (2015).

52 Wierda (2015).
} 
the Rabitat asked the GNC to enact the draft of the 2006 Committee. ${ }^{53}$ Indeed, on 14 October 2015, the GNC issued Law No. 16 to abolish, a.o., Law 4, ${ }^{54}$ and on 17 December of the same year enacted Law No. 20 to address the consequences of such abolition. $^{55}$

Nevertheless, the GNC's intervention is problematic. First, the GNC is no longer the sole governing body, and so cannot enforce these laws in the areas that its rival, the HoR, controls. More importantly, given the way of drafting and enacting these laws, it is not desirable to sustain them as part of reconciliation efforts. There is already a mechanism in place to end the political divide, and, possibly, retain laws and decisions introduced by the rival bodies. The UN sponsored a political dialogue that ended with the signing of a Political Agreement for power sharing on 17 December 2015. The Agreement stipulates that the HoR will be the sole legislature, while the GNC will become a High State Council with strong advisory powers. The executive will be a Government of National Accord (GNA) composed of representatives of both camps. To deal with any laws and decisions the GNC and HoR introduced since August 2014, the Political Agreement provides for a committee to study them "with the aim of finding suitable solutions." 56

If the aim is indeed to find suitable solutions, the reviewing committee should not endorse Laws 16 and 20; they reflect a problematic revolutionary view that has significantly diminished. The failure to achieve the aims of the February revolution has led many Libyans to not only question the GNC and its laws, but also the revolution itself, and think that the situation under Gaddafi's rule was far better. ${ }^{57}$ The pride, hence the power, derived from the association with the revolution is no longer felt, or at least, acknowledged unanimously. It should come as no surprise that the GNC's opponent, the HoR, distanced itself from the revolutionary view and the laws reflecting it. For example, it decided on 2 February 2015 to end the Political Isolation Law. ${ }^{58}$

This way, the Political Agreement can end the divide, an important step towards addressing Law 4 grievances. Still, it will not restore the environment that existed before the country became divided. In the new environment, forms of justice as perceived by the revolutionaries are unlikely to continue. Also, those associated, or perceived to be associated, with the former regime are unlikely to continue to be ignored. It is, therefore, expected that once the debate on Law 4 comes back to life, occupants will actively participate in it.

\footnotetext{
53 Published on the Rabitat's Facebook page: https://www.facebook.com/PropertyOwnersLibya/, accessed 20 January 2016.

54 Al-Jarida al-Rasmia (Official Gazette), Issue No 5, 17/11/2015.

55 Al-Jarida al-Rasmia (Official Gazette), Issue No 1, 1/2/2016.

56 The Libyan Political Agreement. Available online at: https://unsmil.unmissions.org/LinkClick.aspx?fileticket=miXuJYkQAQg\%3D\&tabid=3559\&mid=6187\&language=fr, accessed 20/1/2016.

57 Nation-wide surveys conducted by the Benghazi University Centre for Research and Consulting show this change. In a survey exploring Libyans' opinions on the constitution in 2013, the percentage of those who believed that the situation was worse than it had been under the former regime was $9 \%$, while it became $44.6 \%$ in a survey conducted in 2014 (Zahi Elmogheirbi 2014).

58 BBC News (2015) Libya revokes bill which banned Gaddafi-era officials from office [Online]. Available from: http://www.bbc.com/news/world-latin-america-31104099. Accessed: 20 January 2016.
} 
This would allow for a more objective debate of all aspects of the issue and possible courses of action. For example, one important question is whether awarding large amounts of public money in compensation is possible or even desirable? The cost of a programme of full restitution or compensation has been projected into the billions, ${ }^{59}$ and political developments in the aftermath of the revolution have already demonstrated that compensation programmes can be politically contentious. Public opposition to compensation Law 50/2012 for victims of Gaddafi's prisons, which would have awarded claimants 8,000 LYD for every month they were imprisoned, was so strong that the legislation had to be put on hold. ${ }^{60}$ Moreover, full compensation for large property owners, or complete restitution of their property, will reinstate an extremely wealthy property owning elite. The political sustainability of such a policy was already doubtful. While property claimants clearly have a claim, their complaints regarding disenfranchisement under Gaddafi are not unique. Property claimants may also, like other Libyans, be widows on inadequate pensions, medical patients who have to travel to Tunisia for adequate treatment or underpaid employees in the public sector with second or third jobs.

\section{Conclusion}

This paper argued that in the post Gaddafi era property claimants managed, after struggling for decades, to establish their definition of what constitutes a just solution to their grievances, that is, the restitution of their property, or, when that is unattainable, full compensation. They succeeded, in the absence of occupants, to enshrine this definition in all draft laws dealing with the legacy of Law 4. To do so, they presented themselves as victims of the former regime who, like its other victims, would be entitled to the justice that the February revolution promised to deliver. In contrast, they presented their opponents, the occupants, as the former regime's loyalists. As a result, no effort was made to listen to those occupants' demands if they would dare to utter them. The revolutionary fervour dominant in the immediate aftermath of the 2011 revolution guaranteed the success of such a strategy.

The situation has, however, changed, and the legacy of the 2011 revolution is being re-evaluated by Libyans. New perceptions of the Gaddafi period and its aftermath have lessened the dominance of those deemed as proponents of the revolution, and empowered those considered as its opponents. It is therefore unlikely that when the time comes and the issue of Law 4 is once again on the government agenda, occupants will shy away from having their say on how it should be solved. In that case, the result would be a law which balances the interests of the property claimants and the occupants.

\footnotetext{
59 In 2012, Shaker Dakhil, head of Rabitat, estimated that compensating Libyans whose property was taken under Gaddafi would cost at least \$15 billion (Worth 2012).

60 "Libyan Minister of Finance Refuses to Enforce a Law Compensating Political Prisoners of Gaddafi's Era," Azzaman, 19 June 2012, http://www.azzaman.com/azzamanmobile/index.php/archives/8418, accessed 20 January 2016.
} 
The draft constitution published by the Working Committee of Constitution Drafting Assembly (CDA) on 6 October 2015 has attempted to strike this balance. Article 190 of this draft concerns all victims of human rights violations, but there is a clause that could be read as applicable to Law 4 victims; it obligates the state, a.o., to "guarantee the rights of persons whose real or movable properties have been illegally taken away." The elements that should be taken into account are the rights of the original owner to restitution or compensation, the financial position of the occupant and the constructions added to the property, and the previous administrative and judicial procedures." A balance between the interests of former owners and occupants is clearly sought. ${ }^{61}$

At this point two recommendations with regard to forthcoming policy towards resolving disputes arising from Law 4 seem relevant. The first, at the risk of sounding self-serving as an academic, is that more research needs to be done into the opinions of property claimants, occupants and the general public; the projected social outcomes of any adopted policy (from the comparative perspective of similar property claims in the post-Soviet bloc and post-conflict situations, such as Kosovo and Iraq; the viability of different housing schemes in the Libyan context; and, the financial cost, the (housing, welfare etc.) policy implications and practical implementation of different political solutions (such as which forum will have authority to adjudicate cases). The general public should be informed that this research is undertaken, and interim findings should be carefully disseminated to inform people that the research is progressing. During the fieldwork, property claimants commonly mentioned that they felt they were not being listened to and that the government was doing nothing to deal with their claims. As Mr M put it: "We just want to know that we are not being forgotten."

In addition to conducting additional research, the second recommendation is that Law 4 is integrated into the issues addressed in any future efforts towards transitional justice. During the interviews with property claimants people were always asked what a just solution would be for occupants of contested properties and how long they expected that it would take for the property issue to be resolved by the government. Although the interviewees remained angry towards the occupants involved in their own disputes, all of them readily conceded that people could not simply be made homeless and that resolving the situation would take anything between two to ten years. Every one of them highlighted the fact that security was the pre-eminent national priority, but also usually added that Libya faced many other challenges including an underfunded education system and a chronically inadequate health system. Much of the fury and frustration they expressed was directed against the government, which was accused of being partisan, slow to act and corrupt. It might be that more transparency and inclusivity in government policy will go some way to ameliorating this perception, while allowing all voices involved in Law 4 disputes to be heard in the transitional justice

\footnotetext{
${ }^{61}$ The CDA's Working Committee (2015). First Draft of the Constitution. El-Beida: The Working Committee. Available

at: http://www.libyaschannel.com/wp-content/uploads/2015/10/مسودة-الدستور.pdf accessed 22 January 2016.
} 
process may go some way to forging a level of consensus about a just solution in property disputes.

Open Access This article is distributed under the terms of the Creative Commons Attribution 4.0 International License (http://creativecommons.org/licenses/by/4.0/), which permits unrestricted use, distribution, and reproduction in any medium, provided you give appropriate credit to the original author(s) and the source, provide a link to the Creative Commons license, and indicate if changes were made.

\section{References}

Fitzgerald M, Megerisi T (2015) Libya: whose land is it?. the Legatum Institute, London

Gebril J, El-Tobuli M (2013) Compensation for unlawful detention under Gaddafi's regimze. In: Otto JM, Carlisle J, Ibrahim S (eds) Searching for justice in post-Gaddafi Libya: a socio-legal exploration of people's concerns and institutional responses at home and from abroad. Leiden University: Van Vollenhoven Institute, Leiden, pp 130-141

International Crisis Group (2015) Libya: Getting Geneva Right. Middle East/North Africa Report 157, 26 February 2015. Brussels

Maghur, Azza, al-sina'ah al-tashriyah fi ghiyab al-distour [Legislation Making in the Absence of Constitution] (2008), http://www.lawoflibya.com/forum/showthread.php?t=3595

Muzughy (n.d.) AASA: Musuw'at Tashriyy'at Mahkamat Al-Sha'ab wa Maktab al-Id'aa 'Al-Sha'abi Part 1 Tripoli: al- Markaz al-'Alami li-Dirasat wa-Abhath al-Kitab al-Akhdar (Center for Global Studies and Research on the Green Book) No Year: 437-439

Otman W, Karlberg E (2007) The libyan economy: economic diversification and international repositioning. Springer, Verlag Berlin Heidelberg

Pargeter A (2012) Libya: the rise and fall of Qaddafi. Yale University Press, New Haven

St John RB (2011) Libya: continuity and change. Routledge, London

Vandewalle D (2012) A history of modern Libya, 2nd edn. Cambridge University Press, Cambridge

Wierda M (2015) Confronting Qadhafi's legacy: transitional justice in libya. In: Cole P, McQuinn B (eds) The Libyan revolution and its aftermath. C. Hurst \& Co., Ltd., London, pp 153-174

Williams R (2012) Housing, land and property issues and the response to displacement in Libya. UNHCR Libya Office

Worth RF (2012) Thousands of Libyans struggle with recovery of property confiscated by Qaddafi. The New York Times, 13 May 2012. http://www.nytimes.com/2012/05/14/world/africa/libyansconsider-recovery-of-property-confiscated-by-qaddafi.html

Zahi Elmogheirbi NE (2014) Libyan views regarding the national dialogue survey report. Research and Consulting Center University of Benghazi, Benghazi 